(c) American Dairy Science Association, 2005.

\title{
Invited Review: Bovine Milk Fat Globule Membrane as a Potential Nutraceutical
}

\author{
V. L. Spitsberg \\ BioVita Technologies, Bat Yam, Israel
}

\begin{abstract}
For the last $15 \mathrm{yr}$, a great deal of knowledge has been accumulated on health beneficial factors, protein and nonprotein, of bovine milk fat globule membrane (MFGM). Among the health-beneficial components of the MFGM are cholesterolemia-lowering factor, inhibitors of cancer cell growth, vitamin binders, inhibitor of Helicobacter pylori, inhibitor of beta-glucuronidase of the intestinal Escherichia coli, xanthine oxidase as a bactericidal agent, butyrophilin as a possible suppressor of multiple sclerosis, and phospholipids as agents against colon cancer, gastrointestinal pathogens, Alzheimer's disease, depression, and stress. All of the above compel us to consider bovine MFGM as a potential nutraceutical.

(Key words: bovine milk fat globule membrane, milk anticancer protein, phospholipid, cholesterolemia)
\end{abstract}

Abbreviation key: BRCT $=$ C-terminal domain of BRCA1 protein, $\mathbf{B T N}=$ butyrophilin, $\mathbf{C H D}=$ coronary heart disease, EAE = experimental autoimmune encephalomyelitis, FABP = fatty acid binding protein, MFGM = milk fat globule membrane, $\mathbf{M O G}=$ myelin oligodendrocyte glycoproteins.

\section{INTRODUCTION}

Milk fat in the lactating cow is secreted as myriads of lipid droplets of size 0.1 to $15 \mu \mathrm{m}$. These micro lipid droplets are encircled by a special membrane composed of lipid bilayer and proteins. This membrane has been designated the milk fat/lipid globule membrane (MFGM). The MFGM originates from the plasma membrane of the mammary gland secretory cells by extrusion of lipid droplet from the cell (Kanno, 1990; Mather and Keenan, 1998). Because each lipid droplet in milk has its own membrane envelope, i.e., the MFGM, the lipid droplets are present in milk in a dispersed form and, therefore, do not aggregate with each other. Only after destruction of the structure of the MFGM through,

Received November 20, 2004.

Accepted March 22, 2005.

E-mail: vspits20@hotmail.com. for example, a mechanical force like churning, do the lipid droplets aggregate and subsequently form large fat clumps known as butter. Milk fat globule membrane is composed of proteins and lipids in a 1:1 weight ratio (Kanno, 1990). Analysis of the protein entity of bovine MFGM by SDS-PAGE has demonstrated that MFGM has a large number of polypeptides, at least 50 , ranging from 10 to $300 \mathrm{kDa}$ (Spitsberg and Gorewit, 1998; Mather, 2000). A similar number of protein polypeptides can be seen in human MFGM (Goldfarb, 1997; Spitsberg and Gorewit, 1998). Many of these proteins are present in the MFGM as glycoproteins (Greenwalt et al., 1992; Mather, 2000). Table 1 lists some of the proteins identified in bovine MFGM. The main protein of the MFGM is the glycoprotein butyrophilin (about $40 \%$ of the total proteins of the MFGM), and the second representative protein of the MFGM is xanthine oxidase, which comprises 12 to $13 \%$ of the total. Other proteins are present in MFGM each at $5 \%$ or less. The physiological role of the MFGM proteins is not completely clear despite numerous research studies. However, there are some reasonable suggestions about the physiological function of these proteins in the cell because these proteins are an integral part of the plasma membrane of secretory mammary gland cell.

In recent years, different factors with health beneficial properties have been detected in bovine MFGM, and Table 2 summarizes these findings.

\section{Anticancer Effects}

Observing the effect of some bovine mammary gland proteins and some MFGM proteins on cancer cell growth, Spitsberg and Gorewit (1997a) suggested applying MFGM as a food supplement for preventing the development of cancer, especially breast cancer, in humans. We have shown that one of the isolated proteins of bovine MFGM, fatty acid binding protein (FABP), inhibits the growth of some breast cancer cell lines in vitro at extremely low concentration (Spitsberg et al., 1995; Spitsberg and Gorewit, 2002). We have also demonstrated the presence of the onco-suppressor BRCA1 protein in bovine and human MFGM (Spitsberg and Gorewit, 1998). Recently, a team of French researchers, using affinity chromatography, has detected 
Table 1. Some proteins of bovine milk fat globule membrane (MFGM) as seen by SDS-PAGE.

\begin{tabular}{|c|c|c|c|c|}
\hline Protein & Type & $\begin{array}{l}\text { Molecular } \\
\text { weight, Da }\end{array}$ & Suggested role & Reference \\
\hline Mucin I & Glycoprotein & $>160,000$ & & Mather, 2000 \\
\hline Butyrophilin & Glycoprotein & 66,000 & Lipid secretion & Mather, 2000 \\
\hline CD36 & Glycoprotein & 78,000 & Fatty acid transporter & $\begin{array}{l}\text { Mather, 2000; Sfeir et al, 1997; } \\
\text { Greenwalt et al., } 1992\end{array}$ \\
\hline Fatty acid binding protein (FABP) & & 15,000 & Fatty acid metabolism & Spitsberg et al., 1995 \\
\hline $\mathrm{BRCA}^{1}$ & & 210,000 & Cancer suppressor & Spitsberg and Gorewit, 1997c \\
\hline Mitogen-activated protein kinase ${ }^{2}$ (MAPK) & & 42,000 & Signal transduction & Spitsberg and Gorewit, 1997c \\
\hline Caveolin $^{1}$ & & 27,000 & Signal transduction & Spitsberg and Gorewit, 1997c \\
\hline
\end{tabular}

${ }^{1}$ Protein detected by Western immunoblotting.

${ }^{2}$ Protein was detected by Western immunoblotting. Further work will be needed to establish whether MAPK observed in the MFGM is a cytoplasmic contaminant or it is a complex form with its targeted substrate. Detection of phosphoserine and phosphothreonine in phosphorylated butyrophilin can indicate the presence of serine and threonine specific kinases in the MFGM (Heid et al., 1996; Spitsberg and Gorewit, 1997c).

BRCA1 and BRCA2 in extracts obtained from human and bovine MFGM (Vissak et al., 2002).

The bovine BRCA1 protein reveals $72.5 \%$ sequence identity with the human BRCA1 protein and conservation of amino acids involved in BRCA1 structure and function (Krum et al., 2003). It is noteworthy that, although the bovine $\mathrm{C}$-terminus is truncated by 7 amino acids compared with the human protein, the bovine BRCA1 protein exhibits a similar cell cycle-regulated nuclear expression pattern. The C-terminal domain (BRCT) of the both BRCA1 proteins, human and bovine, has a similar activity in binding the phosphopeptides important in DNA damage responses (Krum et al., 2003; Rodriguez et al., 2003). One of the BRCT domain mutations, Met 1775 $\rightarrow$ Arg, which fails to bind phosphopeptides, relates to predisposition of women to breast and ovarian cancer (Manke et al., 2003). The BRCA2 protein, as well as the BRCA1 protein, is involved in DNA repair processes, although it has an additional function as one of the direct regulators of cytokinesis (Daniels et al., 2004). Our concept on the possible prevention of cancer using bovine MFGM as a food supplement is based on the suggestion that after the consumption of the MFGM, a certain number of inhibitory peptides will be released from the MFGM and subsequently will be absorbed in the digestive tract. The absorbed peptides could enter the bloodstream, and after reaching the organs or tissues, they could exert their inhibitory action on the cells undergoing carcinogenic transformation.

This concept has been inspired by the following facts: 1) a small peptide with 11 amino acid residues identical

Table 2. Components of bovine milk fat globule membrane (MFGM) associated with health benefits.

\begin{tabular}{lll}
\hline Component & Health benefit & Reference \\
\hline BRCA1 & Inhibition of breast cancer & Spitsberg and Gorewit, 1997b; \\
BRCA2 & Inhibition of breast cancer & Vissak et al., 2002 \\
Fatty acid binding protein (FABP) & Cell growth inhibitor & Spitsberg et al., 1995; \\
& & Spitsberg and Gorewit, 2002 \\
Ito et al., 1993 \\
Beta-glucuronidase inhibitor & Inhibition of colon cancer & Bansal and Medina, 1993; Whanger, 2004 \\
FABP as selenium carrier & Anticancer factor & Wang et al., 1998 \\
Helicobacter pylori inhibitor & Prevention of gastric diseases & Ito et al., 1992 \\
Cholesterolemia-lowering factor & Anticholesterolemic & Mana et al., 2004 \\
Butyrophilin & Suppression of multiple sclerosis & Lindmark-Mansson and Akesson, 2000; \\
Vitamin E and carotenoids & Antioxidants & Jensen and Nielsen, 1996 \\
& & Kanno et al., 1991 \\
Vitamin B2 & & Martin et al., 2004; Hancock et al., 2002 \\
Xanthine oxidase & Bactericidal agent & Parodi, 2001 \\
Phospholipids & Inhibition of colon cancer & Noh and Koo, 2004 \\
& Anticholesterolemic & Sprong et al., 2002 \\
& Suppression of gastrointestinal pathogens & Horrocks and Farooqui, 2004 \\
& Anti-Alzheimer, antidepressant & McDaniel et al., 2003 \\
Phosphoproteins & Antistress & Spitsberg and Gorewit, 1997c \\
\hline
\end{tabular}


to the C-terminal of bovine mammary gland FABP was found to be a potent inhibitor of cell growth (Grosse and Langen, 1990; Spitsberg et al., 1995); 2) Japanese researchers (Adachi et al., 1993) demonstrated that the epidermal growth factor (molecular weight 5 to $6 \mathrm{kDa}$ ), given to rats orally with bovine MFGM, was subsequently detected in the portal vein; and 3) some success was achieved in the introduction of therapeutic peptides and proteins through the gastrointestinal tract (Banga, 1995).

It is important to note that in the last 10 to $15 \mathrm{yr}$, there have been several efforts to develop functional foods, including dairy foods. There is a trend to make functional dairy products by introducing into them a certain amount of biologically active peptides generated from milk proteins, to prevent the development of chronic diseases or cancer in humans (Kilara and $\mathrm{Pa}$ nyam, 2003). The concept of functional food is based on the suggested absorption of active peptides in the digestive tract.

The work on inhibition of the growth of experimental tumors by the BRCA1 peptides given orally to animals would be important to justify the application of bovine MFGM as a food supplement for preventing breast and ovarian cancer. We do not exclude the possibility that the above mentioned bovine homolog of human C-terminal BRCT domain, containing Met residue in a highly conserved 31-residue sequence (1756 to 1787), may substitute the mutated (1775 Met $\rightarrow$ Arg) human BRCA1 in harboring the phosphopeptides important in DNA damage response.

There is an interesting observation that bovine MFGM contains a component, likely of protein origin, which could inhibit in vitro the purified $E$. coli betaglucuronidase (Ito et al., 1993), the enzyme involved in the intestinal degradation of glucuronides. The liver plays an essential role in detoxification of many metabolites of endogenous and exogenous origin. The enzyme glucuronyl transferase is important in such a detoxification. Glucuronyl transferase neutralizes the toxic compounds in liver cells through the formation of glucuronides, which are subsequently excreted. Some bacteria in the intestine have the enzyme beta-glucuronidase, which degrades the glucuronides with release of toxic agents, some of which might be carcinogenic, and stimulate the formation of, for example, colon cancer. Therefore, the consumption of MFGM could prevent colon cancer due to the presence of the inhibitor of beta-glucuronidase.

Beside the protein components of MFGM with potential anticancer effects, MFGM also contains an essential amount of phospholipids (Kanno, 1990), one of which, sphingomyelin, can exert anticarcinogenic activity. There is experimental evidence that dietary sphingo- myelin suppresses colon carcinogenesis; sphingosine and ceramide have induced apoptosis in a human adenocarcinoma cell line, and feeding sphingolipids to Min (multiple intestinal neoplasia) mice has reduced the number of colon tumors and aberrant crypt foci (Vesper et al., 1999; Parodi, 2001; Berra et al., 2002; Hertervig et al., 2003; Lemonnier et al., 2003).

\section{Anticholesterolemic Effects}

Howard and Marks (1979) made an interesting observation on the content of serum cholesterol in a group of human volunteers fed a diet rich in butter and in another group fed cream containing an equal amount of fat. Serum cholesterol of the volunteers fed cream did not increase as much as that of the volunteers fed butter. This observation could be explained only by a substantial difference between the 2 diets. Milk fat globule membrane, as an essential component of cream, was suspected as the main factor in lowering the serum cholesterol level. Later, Ito et al. (1992) confirmed this suggestion. These researchers observed a direct inhibitory effect of bovine MFGM on hypercholesterolemia in the rat. This inhibition was explained by a significant binding of cholesterol by MFGM in the intestines of experimental animals. However, these authors did not exclude the influence on serum cholesterol by other substances of the MFGM such as, for example, phospholipids. Recently, Noh and Koo (2004) have demonstrated that one of the milk phospholipids, sphingomyelin, is an effective inhibitor of intestinal absorption of cholesterol in rats. The inhibition has been explained by a direct inhibiting effect of the highly saturated long chains of fatty acyl groups of milk sphingomyelin on the rate of luminal lipolysis, micellar solubilization, and transfer of micellar lipids to the enterocyte.

\section{Effect on Helicobacter pylori Infection}

It has been noted that some forms of stomach diseases such as chronic type B gastritis, peptic ulcer disease, and stomach cancer can etiologically be attributed to the colonization of stomach mucosa with Helicobacter pylori (Cover and Blaser, 1992; Ernst, 1999). Helicobacter pylori can cause in vitro hemagglutination, and this sialic acid-specific process can be inhibited by sialyated glycoproteins, including milk glycoproteins (Hirmo et al., 1998). This observation stimulated further investigation of $H$. pylori infection of the stomach mucosa. Wang et al. (2001) demonstrated that glycoproteins of bovine MFGM were capable of inhibiting the infection of $H$. pylori in a BALB/cA mouse model, and the hemagglutination and adhesion of $H$. pylori in HeLa S3 monolayers. In these experiments, MFGM was obtained from 
bovine buttermilk through a diafiltration process and defatted by extraction with chloroform-methanol. Both preparations of the MFGM, non-defatted and defatted, given orally ( $400 \mathrm{mg} / \mathrm{kg}$ of BW), caused equal healing effect on $H$. pylori infection of gastric mucosa in $\mathrm{BALB} / \mathrm{cA}$ mice, which led to the conclusion that the major role in inhibition of $H$. pylori infection is played by the protein component of MFGM.

\section{Effect of Butyrophilin on Autoimmune Encephalomyelitis}

As indicated above, one of the main proteins of bovine MFGM is a glycoprotein with relative molecular weight of 66 to $67 \mathrm{kDa}$, named butyrophilin (BTN) (Franke et al., 1981). Butyrophilin is a mosaic protein, composed of functionally different peptide domains, and it spans the membrane. The exoplasmic N-terminal domain belongs to the Ig superfamily, and the cytoplasmic Cterminal domain (170 amino acid residues) belongs to B30.2 or rfp domain (Mather, 2000). The B30.2 domain is highly conserved and it can be found in 20 different proteins (Mather, 2000).

Recently, it has been reported that BTN can modulate the encephalitogenic T-cell response to myelin oligodendrocyte glycoprotein (MOG) in experimental autoimmune encephalomyelitis (EAE) related to human multiple sclerosis (Stefferl et al., 2000; Guggenmos et al., 2004). This property of BTN has been explained by the presence in its macromolecule of the extracellular IgVlike domain conserved in MOG and by cross-reactivity with the MOG peptide sequence 76-87. Butyrophilin can trigger the development of experimental EAE, or suppress disease. Mana et al. (2004) demonstrated that treatment of C57BL/6 mice with BTN either before or after immunization with MOG prevents or suppresses the clinical manifestation of EAE. These findings indicate that the consumption of dairy products enriched with MFGM can modulate the pathogenic response to MOG in a positive direction.

\section{Effect of Phospholipids}

We propose that the consumption of the MFGM alone as a nutraceutical or as a dairy food, or the consumption of food products enforced by the MFGM has health benefits due to the presence of phospholipids in the MFGM. Phospholipids of bovine MFGM constitute almost 30\% of the total MFGM lipids. The 3 main MFGM phospholipids are sphingomyelin, phosphatidyl choline, and phosphatidyl ethanolamine. They comprise (weight \%) 19.2 to $23.0,25.7$ to 41.1 , and 27.0 to $35.0 \%$ of total MFGM phospholipids, respectively (Keenan et al., 1977; Kanno, 1990). Currently, it is considered that phospholipids, including milk-derived, affect numerous cell functions including growth and development, molecular transport systems, absorption processes, memory, stress responses, development of Alzheimer's disease, and myelination in the central nervous system (Astaire et al., 2003; McDaniel et al., 2003; Oshida et al., 2003; Horrocks and Farooqui, 2004). Phospholipids also affect the development of colon cancer as discussed above.

\section{MFGM as a Delivery System}

Milk fat globule membrane can also serve as a putative delivery system for microelements such as Se (anticancer agent), fat-soluble vitamins, organic phosphates (see Table 2), and drugs (Sato et al., 1994).

\section{MFGM and Coronary Heart Disease}

There are contradictory observations regarding the effect of consumption of milk or dairy products on the development of coronary heart disease (CHD). Based on epidemiological analysis, Moss and Freed (2003) found that certified death rates from CHD positively correlated country-by-country with milk consumption. They suggested that CHD death could be associated with the nonfat portion of milk, namely, with the MFGM. This suggestion was based exclusively on the finding that the antibody against bovine MFGM circulating in human blood was bound to the fat globules of cow milk but not to those of human milk.

Because the study by Moss and Freed (2003) became one of the arguments to consider bovine MFGM as a component of milk deleterious to the human health (Riccio, 2004), it is necessary to scrutinize the results of the immunological experiments conducted in that study. They determined that the fluorescent-labeled antibody, prepared from the serum of a volunteer (CHD status unknown) against bovine MFGM, could bind to human platelets, large granular lymphocytes, and bovine MFGM, but not to human MFGM, yet a faint crescent of antibody was found trapped under the edge of one human milk fat globule (Moss and Freed, 2003). Although the authors did not indicate which MFGM proteins were recognized by the prepared antibody, the binding of the antibody to human platelets and to bovine MFGM strongly suggests that human platelets and bovine MFGM had a common antigenic site. It is most likely to be the well-known glycoprotein, CD36. This glycoprotein has been identified in the mammary gland, MFGM, platelets, and lymphocytes in humans and other mammals (Greenwalt et al., 1992; Macardle et al., 1996; Tassone et al., 1998). Glycoprotein CD36 is characterized by a highly conserved primary structure 
(Greenwalt et al., 1992). Given this, it is quite surprising that Moss and Freed (2003) were not able to detect the definite binding of the antibody to human MFGM. Overall, the suggestion made by Moss and Freed (2003) about the association of CHD with bovine nonfat milk component (MFGM) should be taken with caution.

A recent epidemiological study conducted in Sweden (Warensjo et al., 2004) reached the conclusion that the estimated intake of milk fat was not associated with cardiovascular risk factors or with increased risk of a first acute myocardial infarction.

\section{ACKNOWLEDGMENT}

The author thanks Natalia Krasnova-Spitsberg for help in preparing the manuscript.

\section{REFERENCES}

Adachi, I., H.-X. Liu, I. Horikoshi, N. Ueno, and H. Sato. 1993. Possibility of lymphatic absorption of epidermal growth factor from intestine. Yakugaku Zasshi 113:256-263. (In Japanese)

Astaire, J. C., R. Ward, J. B. German, and R. Jimenez-Flores. 2003. Concentration of polar MFGM lipids from buttermilk by microfiltration and supercritical fluid extraction. J. Dairy Sci. 86:2297-2307.

Banga, A. K. 1995. Oral delivery of peptide and protein drugs. Pages 217-244 in Therapeutic peptides and proteins. Formulation, processing and delivery systems. Technomic Publishing Co., Lancaster, PA.

Bansal, M., and D. Medina. 1993. Expression of fatty acid binding proteins in the developing mouse mammary gland. Biochem. Biophys. Res. Commun. 191:61-69.

Berra, B., I. Colombo, E. Sottocornola, and A. Giacosa. 2002. Dietary sphingolipids in colorectal cancer prevention. Eur. J. Cancer $1: 193-197$

Cover, T. L., and M. J. Blaser. 1992. Helicobacter pylori and gastroduodenal disease. Annu. Rev. Med. 43:135-145.

Daniels, M. J., Y. Wang, M. Lee, and A. R. Venkitaraman. 2004. Abnormal cytokinesis in cells deficient in the breast cancer susceptibility protein BRCA2. Science 306:876-879.

Ernst, P. 1999. Review article: The role of inflammation in the pathogenesis of gastric cancer. Aliment. Pharmacol. Ther. 13(Suppl. 1): $13-18$

Franke, F. F., H. W. Held, G. Grund, S. Winter, C. Freudenstein, E. Schmidt, E.-D. Jarasch, and T. W. Kennan. 1981. Antibodies to the major insoluble milk fat globule membrane-associated protein: Specific location in apical region of lactating epithelial cells. J. Cell Biol. 89:485-494.

Goldfarb, M. 1997. Two-dimensional electrophoretic analysis of human milk-fat globule membrane proteins with attention to apolipoprotein E patterns. Electrophoresis 18:511-515.

Greenwalt, D. E., R. H. Lipsky, C. F. Ockenhouse, H. Ikeda, N. N. Tandon, and G. A. Jamieson. 1992. Membrane glycoprotein CD36: A review of its role(s) in adherence, signal transduction, and transfusion medicine. Blood 80:1105-1115.

Grosse, R., and P. Langen. 1990. Mammary-derived growth inhibitor. Pages 249-265 in Handbook of experimental pharmacology. Vol. 96. M. B. Sporn, and A. B. Roberts, ed. Springer-Verlag, Berlin, Germany.

Guggenmos, J., A. S. Schubari, S. Ogg, M. Anderson, T. Olsson, I. H. Mather, and C. Linington. 2004. Antibody cross-reactivity between myelin oligodendrocyte glycoprotein and the milk butyrophilin in multiple sclerosis. J. Immunol. 172:661-668.

Hancock, J. T., V. Salisbury, M. C. Ovejero-Boglione, R. Cherry, C. Hoare, R. Eisenthal, and R. Harrison. 2002. Antimicrobial proper- ties of milk: Dependence on presence of xanthine oxidase and nitrite. Antimicrob. Agents Chemother. 46:3308-3310.

Heid, H. W., M. Schnolzer, and T. W. Keenan. 1996. Adipocyte differentiation-related protein is secreted into milk as a constituent of milk lipid globule membrane. Biochem. J. 320:1025-1030.

Hertervig, E., A. Nilsson, Y. Cheng, and R. D. Duan. 2003. Purified intestinal alkaline sphingomyelinase inhibits proliferation without inducing apoptosis in HT-29 colon carcinoma cells. J. Cancer Res. Clin. Oncol. 129:577-582.

Hirmo, S., S. Kelm, and M. Iwersen. 1998. Inhibition of Helicobacter pylori sialic- acid-specific haemagglutination by human gastrointestinal mucins and milk glycoproteins. FEMS Immunol. Med. Microbiol. 20:275-281.

Horrocks, L. A., and A. A. Farooqui. 2004. Docosahexaenoic acid in the diets: Its importance in main and restoration of neural membrane function. Prostaglandins Leukot. Essent. Fatty Acids 70:351-372.

Howard, A. N., and J. Marks. 1979. Effect of milk products on serumcholesterol. Lancet 2:957.

Ito, O., K. Hotta, Y. Goso, K. Ishihara, T. Sugun, M. Morita, T. Wadstrom, and K. Schauer. 1993. Milk fat globule membrane substances inhibit mouse intestinal beta-glucuronidase. J. Food Sci. 58:753-755.

Ito, O., S. Kamata, M. Hayashi, Y. Suzuki, T. Sakou, and S. Motoyoshi. 1992. Inhibitory effect of cream and milk fat globule membrane on hypercholesterolemia in the rat. Anim. Sci. Technol. (Japan) 63:1022-1027.

Jensen, S. K., and K. N. Nielsen. 1996. Tocopherols, retinol, betacarotene and fatty acids in fat globule membrane and fat globule core in cows' milk. J. Dairy Res. 63:565-574.

Kanno, C. 1990. Secretory membranes of the lactating mammary gland. Protoplasma 159:184-208.

Keenan, T. W., E. M. Powell, M. Sasaki, W. N. Eigle, and W. W. Franke. 1977. Membranes of mammary gland. XIV. Isolation and partial characterization of a high molecular weight glycoprotein fraction from bovine milk fat globule membrane. Cytobiologie 15:96-115.

Kilara, A., and D. Panyam. 2003. Peptides from milk proteins and their properties. Crit. Rev. Food Sci. Nutr. 43:607-633.

Krum, S. A., J. E. Womack, and T. F. Lane. 2003. Bovine BRCA1 shows classic responses to genotoxic stress but low in vitro transcriptional activation activity. Oncogene 22:6032-6044.

Lemonnier, L. A., D. L. Dillehay, M. J. Vespremi, J. Abrams, E. Brody, and E. M. Schmelz. 2003. Sphingomyelin in the suppression of colon tumors: Prevention versus intervention. Arch. Biochem. Biophys. 419:129-138.

Lindmark-Mansson, H., and B. Akesson. 2000. Antioxidative factors in milk. Br. J. Nutr. 84(Suppl.):S103-S110.

Macardle, P. J., Z. Chen, C. Y. Shih, C. M. Huang, H. Weedon, Q. Sun, A. F. Lopez, and H. Zola. 1996. Characterization of human leucocytes bearing the IL-3 receptor. Cell. Immunol. 168:59-68.

Mana, P., M. Goodyear, C. Bernard, R. Tomioka, M. Freire-Garabal, and D. Linares. 2004. Tolerance induction by molecular mimicry: Prevention and suppression of experimental autoimmune encephalomyelitis with the milk protein butyrophilin. Int. Immunol. 16:489-499

Manke, L. A., D. M. Lowery, A. Nguyen, and M. B. Yaffe. 2003. BRCT repeats as phosphopeptide modules involved in protein targeting. Science 302:636-639.

Martin, H. M., J. T. Hancock, V. Salisbury, and R. Harrison. 2004. Role of xanthine oxidoreductase as an antimicrobial agent. Infect. Immun. 72:4933-4939.

Mather, I. H. 2000. A review and proposed nomenclature for major proteins of the milk-fat globule membrane. J. Dairy Sci. 83:203-247.

Mather, I. H., and T. W. Keenan. 1998. Origin and secretion of milk lipids. J. Mammary Gland Biol. Neoplasia 3:259-273.

McDaniel, M. A., S. F. Maier, and G. O. Einstein. 2003. "Brainspecific" nutrients: A memory cure? Nutrition 19:955-956.

Moss, M., and D. Freed. 2003. The cow and the coronary: Epidemiology, biochemistry and immunology. Int. J. Cardiol. 87:203-216. 
Noh, S. K., and S. L. Koo. 2004. Milk sphingomyelin is more effective than egg sphingomyelin in inhibiting intestinal absorption of cholesterol and fat in rats. J. Nutr. 134:2611-2616.

Oshida, K., T. Shimizu, M. Takase, Y. Tamura, T. Shimizu, and Y. Yamashiro. 2003. Effect of dietary sphingomyelin on central nervous system myelination in developing rats. Pediatr. Res. 53:580-592.

Parodi, P. W. 2001. Cows' milk components with anti-cancer potential. Aust. J. Dairy Technol. 56:65-73.

Riccio, P. 2004. The proteins of the milk fat globule membrane in the balance. Trends Food Sci. Technol. 15:458-461.

Rodriguez, M., X. Yu, J. Chen, and Z. Songyang. 2003. Phosphopeptide binding specificities of BRCA1 COOH terminal (BRCT) domains. J. Biol. Chem. 278:52914-52918.

Sato, H., H. X. Liu, I. Adachi, M. Ueno, M. Lemaire, and I. Horikoshi. 1994. Enhancement of the intestinal absorption of a cyclosporine derivative fat globule membrane. Biopharm. Bull. 17:1526-1528.

Sfeir, Z., A. Ibrahimi, E. Amri, P. Grimaldi, and N. Abumrad. 1997. Regulation of FAT/CD36 gene expression: Further evidence in support of a role of the protein in fatty acid binding/transport. Prostaglandins Leukot. Essent. Fatty Acids 57:17-21.

Spitsberg, V. L., E. Matitashvili, and R. C. Gorewit. 1995. Association of fatty acid binding protein and glycoprotein CD36 in the bovine mammary gland. Eur. J. Biochem. 230:872-878.

Spitsberg, V. L., and R. C. Gorewit. 2002. Isolation, purification and characterization of fatty-acid-binding protein from milk fat globule membrane: Effect of bovine growth hormone treatment. Pak. J. Nutr. 1:43-48.

Spitsberg, V. L., and R. C. Gorewit. 1997a. Anti-cancer proteins found in milk. CALS News, Vol. 3(5). Cornell University, Ithaca, NY.

Spitsberg, V. L., and R. C. Gorewit. 1997b. Breast ovarian cancer susceptibility protein (BRCA1) in milk, tissue and cells. J. Dairy Sci. 80(Suppl. 1):60.

Spitsberg, V. L., and R. C. Gorewit. 1997c. In vitro phosphorylated bovine milk fat globule membrane proteins. J. Nutr. Biochem. 8:181-189.

Spitsberg, V. L., and R. C. Gorewit. 1998. Solubilization and purification of xanthine oxidase from bovine milk fat globule membrane. Protein Expr. Purif. 13:229-234.
Sprong, R. C., M. F. E. Hulstein, and R. van der Meer. 2002. Bovine milk fat components inhibit food-born pathogens. Int. Dairy J. 12:209-215.

Stefferl, A., A. Schubari, M. Storch, A. Amini, I. Mather, H. Lassm, and C. Linington. 2000. Butyrophilin, a milk protein, modulates the encephalitogenic $\mathrm{T}$ cell response to myelin oligoddendrocyte glycoprotein in experimental autoimmune encephalomyelitis. J. Immunol. 165:2859-2865.

Tassone, P., F. Tuccillo, P. Bonelli, M. C. Turco, L. Cecco, M. Cerra, H. M. Bond, V. Barbieri, and S. D. Venuta. 1998. CD36 is rapidly and transiently upregulated on phytohemagglutinin (PHA)-stimulated peripheral blood lymphocytes analysis by a new monoclonal antibody. Tissue Antigens 51:671-675.

Vesper, H., E. M. Schmel, M. N. Nikolova-Karakashian, D. L. Dillehay, D. V. Lynch, and A. H. Merrill, Jr. 1999. Sphingolipids in food and the emerging importance of sphingolipids to nutrition. J. Nutr. 129:1239-1250.

Vissak, C., D. Lemery, L. Le Corre, P. Fustier, P. Dechelotte, J. C. Maurizis, Y. G. Bignon, and D. J. Bernard-Gallon. 2002. Presence of BRCA1 and BRCA2 proteins in human fat globules after delivery. Biochim. Biophys. Acta 1586:50-56.

Vorbach, C., S. Alistair, and M. R. Capecchi. 2002. The housekeeping gene xanthine oxidoreductase is necessary for milk fat droplet enveloping and secretion: Gene sharing in the lactating mammary gland. Genes Dev. 16:3223-3235.

Wang, X., S. Hirmo, R. Millen, and T. Wadstrom. 2001. Inhibition of Helicobacter pylori infection by bovine milk glycoconjugates in a BALB/cA mouse model. FEMS Immunol. Med. Microbiol. 20:275-281.

Warensjo, E., J. H. Jansson, L. Berglund, K. Boman, B. Ahren, L. Weinehall, B. Lindahl, G. Hallmans, and B. Vessby. 2004. Estimated intake of milk fat is negatively associated with cardiovascular risk factors and does not increase the risk of a first acute myocardial infarction. A prospective case-control study. Br. J. Nutr. 91:635-642.

Whanger, P. D. 2004. Selenium and the relationship to cancer: An up-date dagger. Br. J. Nutr. 91:11-28. 